\title{
Farmers Characteristics in Planting Onion and Non-onion (Allium Ascalonicum L.) at Rejoso District of Nganjuk Regency
}

\author{
Lia Nurvia ${ }^{1}$, Dwi Ratna Hidayati ${ }^{2 *}$ \\ Agribusiness Program Study, Faculty of Agriculture, Trunojoyo University Madura, Jl. Raya Telang, \\ Madura, 69162, Indonesia
}

Received: 28 July 2017; Revised: 30 July 2017; Accepted: 1 Agustus 2017

\begin{abstract}
Nganjuk is one of the central production areas of onion with 140.22 tons production in 2014. It has contributed as much as $11.84 \%$ to the national onion production. On the other hand, SISKAPERBABO mentioned that onion has fluctuated price. However, the fluctuating price of onion does not seem to affect the onion farmers. It is proved by an increase of onion data production in Nganjuk rather than other substitute commodities. The research aims to know the characteristic of farmers in planting onion and nononion commodity at Rejoso District of Nganjuk Regency. The data used in this research is primary data, and respondents are divided into two categories namely onion farmers (30) and non-onion farmers (30). It is analyzed using descriptive qualitative. Research result shows that both onion and non-onion farmers are in productive age (15-55 years), income of onion farmers are mostly $>30.000 .000$ meanwhile non-onion farmers are $<15.000 .000$, the educational background of onion farmers are mostly Senior High School, and non-onion farmers are mostly have not graduated elementary school, the majority of the experience of onion farmers and non-onion farmers ranged between 15- 30 years and land area of both are $<0.5 \mathrm{Ha}$.
\end{abstract}

Key words: farmers characteristics; qualitative descriptive; onion

\section{How to cite:}

Nurvia, L., \& Hidayati, D. R. (2017). Farmers Characteristics in Planting Onion and Non-onion ( Allium Ascalonicum L .) at Rejoso District of Nganjuk Regency. HABITAT, 28(2), 69-74. https://doi.org/10.21776/ub.habitat.2017.028.2.10

\section{Introduction}

Onion (Allium ascalonicum. L) is one of the horticultural commodities of seasonal vegetables with good potential to be developed to increase the income. Onion also contributes to $10.35 \%$ of the national vegetable production of 1,233,984 tons. Furthermore, as many as 956,625 tons or $77.53 \%$ of nation onion productions comes from Java Island. East Java becomes one of the onion production centers in Java Island. East Java is the second center of national onion production after Central Java with the production of 293,179 tons (Fixed Horticulture Rate, 2014).

The amount of onion production in East Java is influenced by the areas of onion production center in East Java. Based on the data of onion production in East Java, there are four regencies with the highest onion production including Nganjuk Regency. Nganjuk regency (BPS of East

*Corresponding Author:

E-mail: nonratna1@gmail.com
Java Province, 2015) states that in 2013, they have contributed $11.84 \%$ on the onion national production and became the largest onion producer in East Java. This is in accordance with the onion production in East Java Year 2012-2014.

The most significant improvement occurred in 2014 with the total production of 140.22 tons or with an increase of 22.72 tons from the previous year (BPS of East Java Province, 2015). The high onion production in Nganjuk Regency is influenced by the areas of onion production in Nganjuk Regency. These areas are spread in five subdistricts namely Sukomoro, Gondang, Rejoso, Bagor, and Wilangan. The sub-district with the highest onion production is Rejoso with the production of 38,086.8 tons in 2013 (Agriculture Office of Nganjuk Regency, 2014).

The increase of onion production in Nganjuk Regency in 2012-2014 proves that many farmers are interested in onion farming. Although most of the farmers know that onion does not have a stable price and they know that this condition is indirectly detrimental for the farmers especially when the onion is valued with low price. Based on 
the information from SISKAPERBAPO, which is information system to know the price of basic commodities from DISPERINDAG (Industry and Trade Service) of East Java concerning the availability and development of the price of basic commodities in East Java, stating that the price of onion at the producer level always experiences price change every day.

Table 1. Onion Production in East Java of 20122014 (Official Gazette of Statistics of East Java Province No.53/08/35/Th.XIII, 2015)

\begin{tabular}{lccc}
\hline \multirow{2}{*}{ Description } & \multicolumn{3}{c}{ Productions (thousand tons) } \\
\cline { 2 - 4 } & $\mathbf{2 0 1 2}$ & $\mathbf{2 0 1 3}$ & $\mathbf{2 0 1 4}$ \\
\hline Nganjuk & 116.51 & 117.50 & 140.22 \\
Probolinggo & 42.97 & 47.28 & 57.04 \\
Sampang & 9.02 & 24.49 & 27.28 \\
Pamekasan & 12.57 & 13.98 & 13.80 \\
\hline
\end{tabular}

Furthermore, the research result from (Ratri et all, 2014) states that the fluctuating price of onion is due to the market mechanism where the price is affected by the import policy of the onion through Ministry of Agriculture Regulation no. 60 of 2012 on Horticultural Product Import Recommendation. This regulation has given a lot of adverse effect on the onion price at the farming level. This is in line with (Restutiningsih et al, 2016), the related research result states that the farmer's motivation in doing the business are intrinsic and extrinsic motivation where the price becomes the intrinsic factor amounted to $73.33 \%$. It is interesting to discuss how the unstable condition of the onion price does not seem to influence the production, especially with the characteristic of the farmers who remain motivated to plant onion comparing to other farmers who do not plant the onion. There may be different factors such as age as stated by (Robbin, 2007) that older farmers do not have lots of enthusiasm and tend to reject the new technological development. It becomes the background for the researcher to know the characteristics of the farmers who plant onion and non-onion in Rejoso Subdistrict.

\section{Research Method}

This research is conducted in Rejoso Subdistrict Nganjuk Regency in October 2015 until May 2017. The sample is determined through Purposive Sampling Method, meanwhile, the number of samples is determined with Accidental
Sampling method. The number of the sample used in this research is 60 respondents divided into two categories namely the farmers of onion amounted to 30 respondents and farmers of non-onion amounted 30 respondents. The data used are primary data and secondary data. Primary data includes the farmer age, education, farming experience, income and land area. Secondary data consists of the data of the number of onion production in East Java, Nganjuk Regency, and Rejoso Regency, the updated price of the onion, the number of population of onion in Rejoso Subdistrict, the monograph data and demographic data of Rejoso Subdistrict. The analysis tool used to answer the problems concerning the characteristic of onion and non-onion farmers is qualitative descriptive analysis explaining the research result in accordance with the interview and the spread of questionnaire and it will be compared with the previous related research.

\section{Result and Discussion}

3.1. The characteristics of Farmers who Cultivate Onion and Non-onion Merah (Allium ascalonicum. L) In the Rejoso District Ngajuk Regency.

The potential of agriculture sector in Rejoso District includes food crops and horticultural crops. One of food crops to be potentially developed is rice crops. Meanwhile, horticultural crops to be potentially developed is onion. The characteristics of the respondents in this research consist of the farmer age, income, education, farming experience and land area. These characteristics are described below in detail.

\subsubsection{Farmer's Age}

The characteristics of the farmer's age can be generally differentiated into productive and non-productive age. Someone can be categorized into productive age if his age is around 15 to 55 years old and if his age $<15$ years old or $>55$ years old then he will be categorized in the nonproductive age (Simanjutak, 2002). According to (Nurdina et al, 2015), in her research titled The Farmer's Motivation in Managing Community Forest in Sukoharjo 1 of Sukoharjo District Pringsewu Regency states that one of the factors that affect the farmer's motivation consists of age variable ranging from $15-65$ years. These are the characteristics of the age of onion and non-onion farmers in the Rejoso Sub district Nganjuk Regency. 
Table 2. The Characteristics of the Onion and Non-onion Farmers Based On Age

\begin{tabular}{ccccccc}
\hline No. & Farmer's & Category & Onion Farmers & \multicolumn{2}{c}{ Non-onion Farmers } \\
\cline { 4 - 6 } & Age (Year) & Frequency & $\begin{array}{c}\text { Percentage } \\
(\boldsymbol{\%})\end{array}$ & Frequency & $\begin{array}{c}\text { Percentage } \\
(\boldsymbol{\%})\end{array}$ \\
\hline 1. & $15-55$ & Productive Age & 26 & 86.7 & 20 & 66.7 \\
2. & $>55$ & Non Productive Age & 4 & 13.3 & 10 & 33.3 \\
\hline
\end{tabular}

Based on Table 2. it can be seen that most of the onion and non-onion (rice) farmers are categorized in the productive age. The farmers who are categorized in the productive age look enthusiastic in doing the agricultural business because they still have physical and energy that work optimally. In addition, farmers with productive age will be able to accept any kind of advancement and development both science and technology that can be applied in the development of the agricultural business. The number of the onion farmers classified as non-productive age $>50$ years old is less than non-onion farmers (rice). The reason is that non-onion farmers tend to think that onion farming will have a greater risk than rice farming. The farmers classified as nonproductive age have more experience in agricultural business, but their way of thinking and method of agricultural business are still conventional and underdeveloped. This is in accordance with the opinion from (Robbin, 2007), who states that older farmers do not have lots of enthusiasm and tend to reject the new technological development. In addition, the research result from (Asih, 2009) also states that the support of farmer characteristics in his productive age, the higher level of education and the experience of farming will motivate the farmer to improve his business intensively.

\subsubsection{Farmer's Income}

The income of onion farmers can be seen from their income in one planting season. The lowest income of onion farmers is $2,500,000$ /planting season and the highest income is $81,000,000 /$ planting season. Meanwhile, the lowest income of non-onion (rice) farmers in one planting season is $1,200,000$ and the highest income is $43,760,000$. These are the income characteristics of onion and non-onion farmers in the Rejoso Subdistrict Ngajuk Regency.

Table 3. Characteristics of Onion and Non-onion Farmers Based on Income

\begin{tabular}{cccccc}
\hline \multirow{2}{*}{ No. } & Farmer's Income & \multicolumn{2}{c}{ Onion Farmers } & \multicolumn{2}{c}{ Non-onion Farmers } \\
\cline { 3 - 6 } & (Rp)/Ha/Planting Season & Frequency & Percentage (\%) & Frequency & Percentage (\%) \\
\hline 1. & $<15,000,000$ & 5 & 16.7 & 21 & 70 \\
2. & $15,000,000-30,000,000$ & 4 & 13.3 & 8 & 26.7 \\
3. & $>30,000,000$ & 21 & 70 & 1 & 3.3 \\
\hline
\end{tabular}

Based on Table 3. it can be seen that the income of onion farmers in Rejoso Subdistrict is mostly > 30,000,000 with the income average amounted to 56,080,375/planting season. The farmers with the income $<15,000,000$ are facing crop failure due to pest and disease accompanied by cheap onion price causing the farmers unable to gain maximum income. This is in line with the research conducted by (Rauf et al, 2015) who states that the income of onion farmers of Lembah Palu variety in Bulupaountu Jaya of Sigi Biromaru Subdistrict Sigi Regency, with the average land area of $0.34 \mathrm{Ha}$ will generate the income amounted to Rp. $21,746,480.24$ per season. Meanwhile, the average income of the farmers with the land area of $1 \mathrm{Ha}$ amounted to Rp. $64,634,792.65$ per season.
The high and low income of the onion farmers are adjusted to the price of the onion at the harvest time. The lowest price of onion accepted by the farmers is 15,000 and the highest price is 32,000 . Although the result of the crops is small if the price of the onion is higher in the market, then the farmers will still be able to get large profit. Additionally, although the result of the harvest is abundant with good quality of onion if the onion price in the market is cheap then the farmers will not be able to generate profit. The result obtained is only able to restore the capital that has been used during one harvest season.

The income of non-onion farmers is lower than onion farmers. The reason is that the commodity price of non-onion (rice) is cheaper than the price of onion. The price of rice at the time 
of the study ranged from $3,000-3,800 / \mathrm{kg}$. Nononion (rice) farmers with the income above $30,000,000$ are those with the land area of more than $1 \mathrm{Ha}$. The average income of the non-onion farmers range from 11,226.,666/planting season. However, non-onion (rice) farmers can sell it at any time when they need money. This has been stated in the research conducted by (Tran et al, 2016), that the motivation of the farmers in the transformation of the crops consists of the perception of the farmers, income, natural changes and available natural resources (land and labor).

\subsubsection{Farmer's Educational background}

The educational background of onion farmers in the Rejoso Subdistrict Nganjuk Regency is spread into several levels of education ranging from elementary school (SD) up to undergraduate. The educational background of non-onion farmers is spread into several levels of education ranging from elementary school (SD) up to Senior High School. These are the characteristics of education of onion and nononion farmers in Rejoso Subdistrict Nganjuk Regency.

Table 4. Characteristics of Onion and Non-onion Farmers Based on Education

\begin{tabular}{cccccc}
\hline \multirow{2}{*}{ No. } & Education Level of & \multicolumn{2}{c}{ Onion Farmers } & \multicolumn{2}{c}{ Non-onion Farmers } \\
\cline { 3 - 6 } & The Farmers & Frequency & Percentage & Frequency & Percentage \\
\hline 1. & Not completing & 6 & 20 & 8 & 26.7 \\
& elementary school & & & & 46.7 \\
2. & Elementary School & 8 & 26.7 & 14 & 16.7 \\
3. & Junior High School & 4 & 13.3 & 5 & 10 \\
4. & Senior High School & 10 & 33.3 & 3 & 0 \\
5. & Undergraduate & 2 & 6.7 & 0 & \\
\hline
\end{tabular}

Based on Table 4. it can be seen that most of the educational background of the onion farmers in Rejoso Subdistrict is Senior High School. The high and low of someone's educational background will be affected by the attitude and behavior of the farmers in carrying out their agricultural business. Farmers with high educational background are more likely open minded with the wider perspective in accepting the technological advancement than farmers with the lower educational background. The result in the field shows that although most of the onion farmers only have senior high school as their educational background but lower education level of the onion farmers is not an obstacle of the farmers to do the agricultural business of onion. The reason is that the farmers can still directly practice the planting and harvesting through the experience they have gained. In addition, the farmers have high enthusiasm in following the activity or forum of farmers group and also to contribute to share the information among the farmers. So, these are the levels of education of onion farmers in Rejoso Subdistrict Nganjuk Regency.
Meanwhile, non-onion (rice) farmers are mostly graduated from Elementary School (SD), the low education of the farmers affect their mindset to keep planting rice because they are afraid of the risk failure when planting onion. This is in line with the opinion of (Rukka and Wahab, 2013), their research result discusses that the low level of education affects the farmers' ability in implementing new innovation. However, this is no in line with what has been delivered by (Zuriyani, 2010) who states that someone's high level of education does not guarantee that he has better knowledge about agricultural business.

\subsubsection{Agricultural Business Experience}

Farmer's experience is the length of time spent by the farmer in undergoing the onion agricultural business. Most of the farmer's experience in onion agricultural business range between 15 to 30 years. These are the characteristics of agricultural business experience of onion and non-onion farmers in Rejoso Subdistrict Nganjuk Regency. 
Table 5. Characteristics of Onion and Non-onion Farmers Based on the Length of Agricultural Business Experience

\begin{tabular}{cccccc}
\hline \multirow{2}{*}{ No. } & Length of Agricultural & \multicolumn{2}{c}{ Onion Farmers } & \multicolumn{2}{c}{ Non-onion Farmers } \\
\cline { 3 - 6 } & Business Experience (Year) & Frequency & Percentage & Frequency & Percentage \\
\hline 1. & $<15$ & 4 & 13.3 & 0 & 0 \\
2. & $15-30$ & 22 & 73.3 & 30 & 100 \\
3. & $>30$ & 4 & 13.3 & 0 & 0 \\
\hline
\end{tabular}

The length of agricultural business experience cannot guarantee the success of the farmer in planting the onion. The reason is the experience of agricultural business experience of one onion farmer is different than other farmers. According to the farmers, there is no need for any guidance in conducting onion agricultural business because every farmer has his own way in planting, maintaining and facing pest and disease issue or other issues. Most of the onion farmers are in the range of 15-30 years old and it indicates that they have enough experience in conducting onion agricultural business.

Based on Table 5, it can be seen that the agricultural business of non-onion farmers ranges from 15-30 years. The reason is that most of the non-onion (rice) farmers are used to plant the rice.
According to the farmers, they will face smaller risk when planting rice. If it gets attacked by pests, the farmers can still generate result even though the result is not maximal. Similarly, the season condition that produces a different quantity of production as described by (Widyantara and Yasa, 2013) that climate contributes to the risk of onion agricultural business and the highest risk is during the rainy season.

\subsubsection{Land Area}

The land area owned by the onion farmers is very diverse range from $0.19 \mathrm{Ha}$ to $1 \mathrm{Ha}$. These are the characteristics of the land area of onion and non-onion farmers in Rejoso Subdistrict Nganjuk Regency.

Table 6. Characteristics of Onion and Non-onion Farmers Based on the Land Area

\begin{tabular}{cccccc}
\hline No. & Land Area (Ha) & \multicolumn{2}{c}{ Onion Farmers } & \multicolumn{2}{c}{ Non-onion Farmers } \\
\cline { 3 - 6 } & & Frequency & Percentage & Frequency & Percentage \\
\hline 1. & $<0.5$ & 24 & 80 & 17 & 56.7 \\
2. & $0.5-1$ & 6 & 20 & 12 & 40 \\
3. & $>1$ & 0 & 0 & 1 & 3.3 \\
\hline
\end{tabular}

Most of the onion and non-onion farmers have a land area of less than $0.5 \mathrm{Ha}$ with an average land area of onion farmers of $0.245 \mathrm{Ha}$ and the average land area of non-onion farmers of $0.467 \mathrm{Ha}$. Non-onion farmers have larger land area than onion farmers. The reason is that non-onion farmers have a smaller risk if the farmers facing crops failure. The loss that has to be faced by nononion farmers is lower than onion farmers. The reason is that the capital used in planting the rice is a lot cheaper than planting onion.

Meanwhile, in onion agricultural business, the wider the land area owned by the farmers the higher the modal that has to be bear by the farmers. Similarly, the risk of failure can be higher when planting onion because the farmers cannot ensure its success. The success and failure of the farmers in planting onion depend on the fate and fortune of each farmer or what they often called bejo beji (Javanese). Although the farmer has large land, if he does not have enough capital to buy onion seeds, there will be smaller chance that the farmer will plant onion. Conversely, although the farmer does not have land to grow crops and he has his own onion seeds, he will be able to plant the onion.

\section{Conclusion}

Based on the research result that has been done, it can be concluded that the characteristics of the farmers in planting onion in Rejoso Subdistrict Nganjung regency are as follows. Most of the onion and non-onion (rice) farmers are categorized in the productive age (15-55 years old), the income of onion farmers is mostly > $30,000,000$ while the income of non-onion farmers is mostly >15,000,000, most of the educational background of the onion farmers is Senior High School, but most of the non-onion farmers did not graduate of 9-Year Compulsory Education, the agricultural business experience of onion and non-onion farmers ranges from 15-30 
years and most of the onion and non-onion farmers have a land area of less than $<0.5 \mathrm{Ha}$. These results show that the fundamental characteristics difference in income and education where onion farmers have higher education and income than non-onion farmers. The government is expected to give further socialization to the non-onion farmers and to give support in the form of counseling program concerning onion as the agricultural commodity in Nganjuk regency. Further research is expected to explore more the relationship of the characteristics of farmers with the downstream product strategy of onion through the farmers' marketing communication capability and valueadded as an effort to improve the farmers' bargaining position.

\section{References}

Asih, Dewi N. 2009. Analisis Karakteristik dan Tingkat pendapatan Usahatani Bawang Merah di Sulawesi Tengah. Jurnal Agroland Vol 16 No 1. 53-59, Maret 2009.

BPS Provinsi Jatim. 2015. Berita Resmi Statistik Produksi Bawang Merah Di Jawa Timur Tahun 2012- 2014 No. 53/08/35/Th.XIII, 3 Agustus 2015. https://webcache.googleusercontent.com/se arch?q=cache:BjWpS-

FjBSoJ:https://batukota.bps.go.id/website/ brs_ind/brsInd-

20150813013556.pdf $+\& \mathrm{~cd}=1 \& \mathrm{hl}=\mathrm{en} \& \mathrm{ct}=$ clnk\&gl=id.

Dinas Pertanian Kabupaten Nganjuk. 2014. Perkembangan Tanaman Bawang Merah Tahun 2013.

Nurdina, I. F., Asihing, K.,Rudi, H. 2015. Motivasi Petani Dalam Mengelola Hutan Rakyat di Desa Sukoharjo 1 Kecamatan Sukoharjo Kabupaten Pringsewu. Jurnal Sylva Lestari Vol. 3 No. 3, September 2015 (51-62).

Pusat Data dan Informasi Pertanian. 2014. Angka tetap Hortikultura. http://aplikasi.pertanian.go.id/bdsp/newko m.asp.

Ratri, T. K., Sarwono, Ainul, L. 2014. Regulasi Tata Niaga Bawang Merah Yang Berkeadilan (Studi pada Dinas Pertanian, Petani Bawang Merah dan Pedagang Bawang Merah di Kabupaten Nganjuk). Jurnal Administrasi Public (JAP), Vol. 2 No. 5 Hal. 857-863.
Rauf, R. A., Saiful, D., Atik, A. 2015. Pengembangan Usahatani Bawang Merah Varietas Lembah Palu. Agriekonomika, ISSN 2301-9948 e ISSN 2407- 6260 volume 4, Nomor 2, Oktober 2015.

Restutiningsih, N. P., I Ketut, S. D., I Wayan, S. 2016. Motivasi petani dalam Berusahatani Holtikultura di Desa Wisata Candikuning, Kecamatan Baruriti Kabupaten Tabanan. Ejurnal Agribisnis dan Agrowisata. Vol. 5, No. 1, Januari 2016.

Robbin, S. P. 2007. Perilaku Organisasi. Jakarta: PT Indeks.

Rukka, H dan Arman, W. 2013. Faktor - Faktor Yang Mempengaruhi Motivasi Petani Dalam Pelaksanaan Kegiatan P2BN Di Kecamatan Barru, Kabupaten Barru. Jurnal Agrisistem, Juni 2013, Vol. 9 No.1.

Simanjutak, P. 2002. Pengantar Sumber Daya Manusia. Jakarta: LembagaPenerbit UI.

Tran, P. G dan Nguyen, T. P. C. 2016. Motivation of Farmers on the Third Rice Crop Tranformation in the Context of Change of Naturaland Socio-Economic Characteristics- Case Study in an Giang Province- Mekong delta- Vietnam. International Journal of Environment, Ecology, Family and Urban Studies (IJEEFUS). Vol. 6, Issue 3, Jun 2016, 3-10.

Widyantara, W dan Yasa, N. S. 2013. Iklim Sangat Berpengaruh Terhadap Risiko Produksi Usahatani Bawang Merah (Allium ascalonicum. L). E- Jurnal Agribisnis dan Agrowisata 2(1): 32-3010. Faktor- faktor yang Mempengaruhi Keputusan Petani Melakukan Alih Fungsi Lahan Pertanian Kelahan Non Pertanian di Kecamatan Kuranji dan Kecamatan Koto Tangah Kota Padang. Jurnal Agroekonomi Vol.25, No.2: $1-20$. 